\title{
The importance of environmental-forest education in managing information on natural resources
}

\author{
BEATA SADOWSKA \\ Department of Economics, Finance and Management \\ University of Szczecin \\ Mickiewicza 64, 71-101 Szczecin \\ POLAND \\ ADAM LULEK
Department of Economics, Finance and Management
University of Szczecin
Mickiewicza 64, 71-101 Szczecin
POLAND
}

Abstract: Contemporary conditions of socially responsible economy underline the growing demand and importance of information on natural resources. Care for environmental protection and shaping sustainable development is reflected in many legal acts, documents and school textbooks in Poland. This information, through its disclosure and sharing, contributes to the dissemination of knowledge in the field of environmental protection and sustainable development, while shaping the pro-environmental behaviour of the public. Environmental-forest education is of key importance in managing information on natural resources. The main purpose of this article is to (1) determine the number of activities of selected entities conducting environmental-forest education, (2) identify the strengths and weaknesses of environmental-forest education, (3) propose changes determining effective management of information on natural resources using environmental-forest education. The following research methods were used in the article: literary critical analysis, surveys, qualitative methods (case study), snowball method and tabular techniques for presenting results.

Key-Words: environmental-forest education, education centres, information management, knowledge, natural resources, environment

Received: April 13, 2020. Revised: August 16, 2020. Accepted: August 25, 2020. Published: August 31, 2020.

\section{Introduction}

The aim of education is to gain knowledge about life and the surrounding world. One of the elements of education is the dissemination of knowledge about the natural environment, natural resources and the role of ecosystems in everyone's life. The goal of environmental-forest education is to shape full awareness and arouse public interest in interrelated environmental, social, economic and cultural issues. Managing information on natural resources enables individuals to acquire knowledge and competences that are necessary to improve the state of the natural environment. Access to information on natural resources determines the creation of new behaviour patterns and attitudes, values and beliefs of individuals, groups; it is a personal responsibility and ethical behaviour [1].

The general purpose of environmental-forest education in managing information on natural resources is to raise the level of environmental awareness and shape the environmental attitudes of society by promoting the principles of sustainable development [2]. Moreover, its aim is to shape proenvironmental behaviour among adults, the disabled, children and young people, as well as social activation, i.e. building civil society in the field of natural resource protection. These activities are undertaken on a large scale by Państwowe Gospodarstwo Leśne Lasy Państwowe (The State Forests National Forest Holding (PGL LP, LP)), in all voivodeships in Poland, supplemented by the activities of National Parks, Environmental Education Centres and other entities [3].

The State Forests conduct sustainable forest management, i.e. activities aimed at shaping the structure of forests and their use in a manner and pace that ensures the lasting preservation of their biodiversity, vitality and ability to fulfil, now and in the future, all important protective, economic and social functions without harming other ecosystems 
[4,5]. Properly conducted environmental-forest education contributes to the management of information on natural resources and is an element of modern forest management.

The conducted empirical research that was limited to one voivodeship depicts only a fragment of reality, and thus the following article constitutes a contribution to further in-depth research on the role of environmental-forest education in managing information on natural resources.

Most of the literature items in the article, concern the issues of state forests and forest education. Sustainable development is also an important area touched by authors who write about forestry. Finally, there were also items on broadly understood education, including environmental education.

Few researchers are concerned with the management of environmental information. An even smaller percentage deals with this topic in the area of forests. Some relevant studies can be found in [6] and [7]. This study completes the theoretical gap in the study of the importance of nature and forest education in the management of information on nature resources, it also supplements the empirical gap resulting from poor recognition of information management on nature resources in Poland, especially by National Parks. Considerations at the general level and formulated general conclusions and recommendations can be used by all countries by implementing specific educational programs, by enrolling in science syllabuses, through lectures, lectures, competitions.

The study is useful for journal readers as it touches upon several scientific areas. Among them there is broadly understood education, environmental protection, sustainable development, information and natural resources management. The article is a kind of multidisciplinary study that briefly addresses several areas of the journal.

\section{Problem Formulation}

The management of natural resources puts new tasks before business units in implementing the idea of sustainable socio-economic development of the country [8]. Natural resources, including forests, must be managed by realizing environmental, economic and social benefits. The implementation of these benefits should be disclosed to stakeholders.

Information on the management of natural resources is generated through environmental-forest education, which contributes to the creation of knowledge about natural resources. When defining the research area, the author asked herself the following research questions:

1. What entities, apart from State Forests units (forest inspectorates), deal with environmental-forest education in Zachodniopomorskie voivodeship?

2. What forms of environmental-forest education are preferred by these entities?

3. What is the number of participants in educational activities?

4. What costs and expenses are allocated to education by these entities?

5. What are the strengths and weaknesses of environmental-forest education?

6. Does environmental-forest education contribute to managing information on natural resources?

The main purpose of this article is to (1) determine the number of activities of selected entities conducting environmental-forest education, (2) identify the strengths and weaknesses of environmental-forest education, (3) propose changes determining effective management of information on natural resources using environmental-forest education.

\subsection{Materials and methods}

The research process was divided into four stages: preparation of the research, its conduct, preparation of the results and their description. The condition for obtaining valuable results is the optimal selection of research methods, techniques and tools. The following research methods were used in the article: literary critical analysis, surveys, qualitative methods (case study), snowball method and tabular techniques for presenting results. The critical analysis of the literature was aimed at assessing the state of knowledge about natural resources, knowledge regarding information management, and the importance of environmental-forest education in the aspect of contemporary problems of forest management.

During the stage of gathering the actual knowledge, the observation method, the structured interview technique (interviews were carried out with the representatives of entities conducting environmental-forest education), and the diagnostic poll method (surveys) were applied. Case studies were used in the empirical part that was aimed at exemplifying the activities related to environmentalforest education. Nowadays, case study is considered one of the basic methods of qualitative research. It involves studying one or more objects with high internal complexity when there are many relations with the environment. 
The research procedure adopted in the article is consistent with the inductive method, which includes observing and recording facts, and deriving research observations in the form of generalizations. Interviews with representatives of entities conducting environmental-forest education were carried out in the period from June to July, while the survey was carried out in the period from July to August 2019. The research area covered Zachodniopomorskie voivodeship. The subjects of the study were four entities: two National Parks and two Environmental Education (environmentalforest) Centres.

The research survey covered the following issues:

1. Forms of environmental-forest education.

2. Number of participants in classes covering environmental-forest education.

3. Expenditure related to environmental-forest education.

4. Strengths of environmental-forest education.

5. Weaknesses in the implementation of tasks in the field of environmental-forest education.

The respondents did not give any answer regarding expenses and costs related to environmental-forest education.

In the case of the snowball method (nonprobability sampling method), the respondents recruited other respondents for the study.

\section{Problem Solution - results}

Poland, like other European Union countries, implements the programme of environmental education of the society, including environmentalforest education, some of which goals are to raise awareness, change attitudes and behaviour of the population. Environmental education is carried out both at the level of formal education implemented by educational units, as well as under the so-called informal education conducted by, among others, national parks, environmental education centres, botanical and zoological gardens, as well as individual units of the State Forests. Non-formal education uses natural resources, natural values of the immediate surroundings, nature reserve sites and educational trails.

The research results confirm that a significant role in the management of information on natural resources is played by the State Forests, which through environmental-forest education contribute to creating knowledge about forests, the idea of sustainable socio-economic development of the country, environmental protection, and preservation of the environment for the development of plants, animals and fungi. The State Forests are the leader in terms of the conducted activities covering various forms of environmental-forest education, with the number of participants of educational classes organized by the State Forests being incomparably high when compared to other entities that organize similar events. Survey results confirm that national parks and environmental education centres only hold a supportive function to State Forests in creating knowledge about natural resources. It is worth noting that the management of information on the natural environment and shaping ecological attitudes of the society takes place using various forms of environmental-forest education, as presented in Table 1.

\section{Table 1. Forms of environmental-forest education}




\begin{tabular}{|c|c|c|c|c|c|}
\hline Forms of & \multicolumn{5}{|c|}{ Years } \\
\hline & 2015 & 2016 & 2017 & 2018 & In total \\
\hline \multicolumn{6}{|c|}{ The State Forests, including Zachodniopomorskie voivodeship } \\
\hline $\begin{array}{l}\text { Forms of } \\
\text { environmental- } \\
\text { forest education in } \\
\text { the State Forests in } \\
\text { total }\end{array}$ & 34511 & 34204 & 32394 & no data & 101109 \\
\hline $\begin{array}{l}\text { Selected education } \\
\text { forms } \\
\text { (Zachodniopomorsk } \\
\text { ie voivodeship) }\end{array}$ & 2031 & 1874 & 1922 & no data & 5827 \\
\hline \multicolumn{6}{|c|}{ National Parks ${ }^{1}$} \\
\hline & A & B & A & $\mathrm{B}$ & \\
\hline $\begin{array}{l}\text { Field lessons and } \\
\text { guided tours }\end{array}$ & 16 & 4 & 11 & 10 & 41 \\
\hline Educational trails & 38 & - & 13 & - & 51 \\
\hline $\begin{array}{l}\text { Thematic } \\
\text { workshops }\end{array}$ & 14 & 4 & 14 & 26 & 58 \\
\hline $\begin{array}{l}\text { Meetings with } \\
\text { foresters }\end{array}$ & 36 & 41 & 14 & 77 & 168 \\
\hline $\begin{array}{l}\text { Meetings with } \\
\text { environmentalists }\end{array}$ & 13 & 2 & 7 & 2 & 24 \\
\hline Talks, lectures & 49 & 4 & 44 & 4 & 101 \\
\hline Contests & 50 & 2 & 49 & 0 & 101 \\
\hline Events & 2 & 0 & 2 & 1 & 5 \\
\hline Exhibitions & 7 & 2 & 2 & 3 & 14 \\
\hline In total: & 225 & 59 & 156 & 123 & 563 \\
\hline \multicolumn{6}{|c|}{ Environmental Education Centres $^{2}$} \\
\hline & $\mathrm{C}$ & $\mathrm{D}$ & $\mathrm{C}$ & $\mathrm{D}$ & \\
\hline $\begin{array}{l}\text { Field lessons and } \\
\text { guided tours }\end{array}$ & 0 & 183 & 0 & 190 & 373 \\
\hline Educational trails & 0 & 0 & 0 & 0 & 0 \\
\hline $\begin{array}{l}\text { Thematic } \\
\text { workshops }\end{array}$ & 39 & 228 & 17 & 321 & 605 \\
\hline $\begin{array}{l}\text { Meetings with } \\
\text { foresters }\end{array}$ & 0 & 0 & 0 & 0 & 0 \\
\hline $\begin{array}{l}\text { Meetings with } \\
\text { environmentalists }\end{array}$ & 0 & 0 & 0 & 0 & 0 \\
\hline Talks, lectures & 0 & 7 & 0 & 7 & 14 \\
\hline Contests & 1 & 0 & 1 & 0 & 2 \\
\hline Events & 0 & 7 & 0 & 6 & 13 \\
\hline Exhibitions & 0 & 4 & 0 & 5 & 9 \\
\hline In total: & 40 & 429 & 18 & 529 & 1016 \\
\hline
\end{tabular}

Source: own elaboration based on empirical research.

In national parks located in Zachodniopomorskie voivodeship, the most common form of environmental-forest education are meetings with foresters, talks, lectures and organized contest. It should be emphasized that the number of conducted, organized activities and events in national park $\mathrm{A}$ is significantly higher than

\footnotetext{
${ }^{1}$ Two National Parks from Zachodniopomorskie voivodeship took part in the study. They were designated as National Park A and B.

2 Two National Environmental Education Centers from Zachodniopomorskie voivodeship took part in the study. They were designated as National Park C and D.
}

in national park B. It seems reasonable that an educational trail should be created in national park B. In environmental-forest education centres located in Zachodniopomorskie voivodeship, the most common form of environmental-forest education are thematic workshops as well as guided field lessons. These centres neither conduct classes in the field of environmentalforest education on educational trials, nor organize meetings with foresters and ecologists. They give talks and lectures to a moderate extent. They hardly ever organized any contest during the period considered, with the exhibitions taking place only 9 times.

Other forms of environmental-forest education that are organized from time to time by respondents include:

25th Anniversary of the National Park, Children's day, Święta Jabłka (Festival of Apple), Earth Days, Astronomy workshops, Jarmark Jakubowy (Jacob Fair), Distribution of "Wydra i Przyjaciele" ("Otter and Friends"), Film screenings.

Table 2 below presents the results of empirical research showing the number of participants in educational activities.

Table 2. Number of participants in educational classes

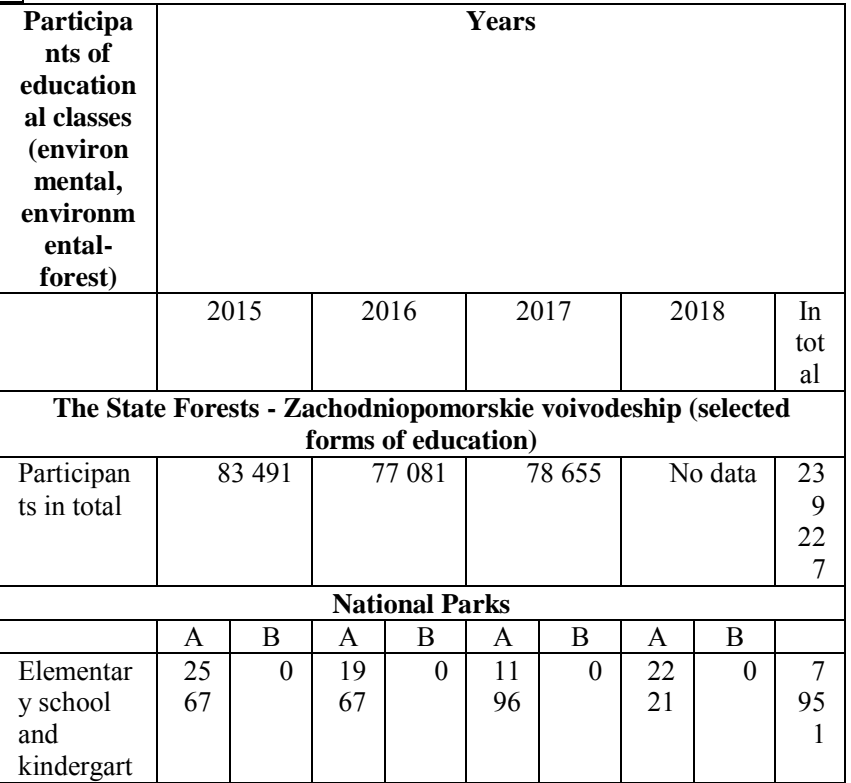




\begin{tabular}{|c|c|c|c|c|c|c|c|c|c|}
\hline \multicolumn{10}{|l|}{$\begin{array}{l}\text { en } \\
\text { students }\end{array}$} \\
\hline High & 43 & 119 & 46 & 136 & 36 & 128 & 23 & 109 & $\mathbf{5 0}$ \\
\hline $\begin{array}{l}\text { school } \\
\text { students }\end{array}$ & 0 & 36 & 0 & 58 & 5 & 30 & 3 & 42 & $\begin{array}{r}85 \\
4\end{array}$ \\
\hline $\begin{array}{l}\text { University } \\
\text { students }\end{array}$ & 0 & 0 & 0 & 0 & 0 & 0 & 0 & 0 & 0 \\
\hline Adults & 32 & 197 & 21 & 164 & 40 & 190 & 16 & 276 & 9 \\
\hline & 2 & 7 & 4 & 5 & 0 & 8 & 8 & 7 & $\begin{array}{r}40 \\
1\end{array}$ \\
\hline $\begin{array}{l}\text { Persons } \\
\text { with } \\
\text { reduced } \\
\text { mobility }\end{array}$ & 0 & 0 & 61 & 0 & 44 & 0 & 30 & 0 & $\begin{array}{r}13 \\
5\end{array}$ \\
\hline Other & 0 & 0 & 0 & 0 & 0 & 0 & 0 & 0 & 0 \\
\hline In total: & 33 & 139 & 27 & 153 & 20 & 147 & 26 & 137 & 68 \\
\hline & 19 & 13 & 02 & 03 & 05 & 38 & 52 & 09 & 34 \\
\hline \multicolumn{10}{|c|}{ Environmental education centres } \\
\hline & $\mathrm{C}$ & $\mathrm{D}$ & $\mathrm{C}$ & $\mathrm{D}$ & $\mathrm{C}$ & $\mathrm{D}$ & $\mathrm{C}$ & $\mathrm{D}$ & \\
\hline Elementar & 11 & 900 & 67 & 700 & 10 & 740 & 83 & 700 & 34 \\
\hline $\begin{array}{l}\text { y school } \\
\text { and } \\
\text { kindergart } \\
\text { en } \\
\text { students }\end{array}$ & 60 & 0 & 9 & 0 & 39 & 0 & 6 & 0 & 11 \\
\hline $\begin{array}{l}\text { High } \\
\text { school } \\
\text { students }\end{array}$ & 0 & 400 & 0 & 958 & 0 & 400 & 0 & 272 & $\begin{array}{r}2 \\
03 \\
0\end{array}$ \\
\hline $\begin{array}{l}\text { University } \\
\text { students }\end{array}$ & 0 & 71 & 0 & 100 & 0 & 98 & 0 & 100 & $\begin{array}{r}36 \\
9 \\
\end{array}$ \\
\hline Adults & 0 & $\begin{array}{r}554 \\
5\end{array}$ & 0 & $\begin{array}{r}630 \\
2\end{array}$ & 0 & $\begin{array}{r}500 \\
0\end{array}$ & 0 & $\begin{array}{r}290 \\
0\end{array}$ & $\begin{array}{l}19 \\
74\end{array}$ \\
\hline $\begin{array}{l}\text { Persons } \\
\text { with } \\
\text { reduced } \\
\text { mobility }\end{array}$ & 0 & 90 & 0 & 75 & 0 & 192 & 0 & 102 & $\begin{array}{r}45 \\
9\end{array}$ \\
\hline Other & 0 & 0 & 0 & 0 & 0 & 0 & 0 & 0 & 0 \\
\hline In total: & 11 & 151 & 67 & 144 & 10 & 130 & 83 & 103 & 56 \\
\hline & 60 & 06 & 9 & 35 & 39 & 90 & 6 & 74 & 71 \\
\hline
\end{tabular}

Source: own elaboration based on empirical research.

The State Forests use various forms of forest education in society, among others: field lessons and guided tours, lessons in education centres of forest research institute, meetings with foresters inside and outside schools, knowledge, art and literary competitions. The State Forests are a leading entity in the number of participants in educational activities. They cooperate in the field of environmental-forest education with schools and kindergartens, community centres, nongovernmental organizations, media, national parks and environmental education centres.

The participants of educational classes in national parks are usually high school students and adults. It is interesting that in the studied National Park B forms of environmental-forest education were not used by elementary and kindergarten students or people with reduced mobility in the analysed period. It should be noted that in the case of National Park A, there is a downward trend in the participation of disabled people in activities involving environmental-forest education.
Environmental education centres usually organize classes for elementary and kindergarten students as well as adults. In the case of these entities, the participation of disabled people and university students in organized forms of environmental-forest education is also noted.

Both national parks and environmentalforest education centres should be recognized as entities supporting the State Forests in activities aimed at generating information and creating knowledge about natural resources among the society.

The respondents were asked about the strengths of environmental-forest education (Table $3)$. The received answers stated that environmentalforest education is becoming more and more popular, especially among teachers and elementary school students, and that environmental-forest awareness is growing.

Table 3. Strengths of environmental-forest education by the number of respondents' answers (\%)

\begin{tabular}{|c|c|c|c|c|c|}
\hline & $\begin{array}{c}\text { Definitel } \\
\text { y not }\end{array}$ & $\begin{array}{c}\text { Rathe } \\
\text { r not }\end{array}$ & $\begin{array}{l}\text { I have } \\
\text { no } \\
\text { opinio } \\
\text { n }\end{array}$ & $\begin{array}{l}\text { Rathe } \\
\text { r yes }\end{array}$ & $\begin{array}{l}\text { Definite } \\
\text { ly yes }\end{array}$ \\
\hline $\begin{array}{l}\text { Environmental- } \\
\text { forest education } \\
\text { is becoming } \\
\text { more and more } \\
\text { popular, } \\
\text { especially } \\
\text { among teachers } \\
\text { and elementary } \\
\text { school students }\end{array}$ & 0 & 25 & 25 & 25 & 25 \\
\hline $\begin{array}{l}\text { The } \\
\text { environmental } \\
\text { and forest } \\
\text { awareness of the } \\
\text { society is } \\
\text { increasing }\end{array}$ & 0 & 0 & 25 & 75 & 0 \\
\hline $\begin{array}{l}\text { About } 50 \% \text { of } \\
\text { teachers who } \\
\text { teach about } \\
\text { issues regarding } \\
\text { environmental- } \\
\text { forest education } \\
\text { are involved in } \\
\text { this process }\end{array}$ & 0 & 50 & 25 & 25 & 0 \\
\hline $\begin{array}{l}\text { Environmentalis } \\
\text { ts and foresters } \\
\text { are becoming } \\
\text { more creative } \\
\text { and have more } \\
\text { and more } \\
\text { pedagogical } \\
\text { experience }\end{array}$ & 0 & 0 & 25 & 25 & 50 \\
\hline $\begin{array}{l}\text { Local media is } \\
\text { becoming more } \\
\text { and more } \\
\text { interested in } \\
\text { environmental- } \\
\text { forest activities }\end{array}$ & 0 & 0 & 25 & 75 & 0 \\
\hline $\begin{array}{l}\text { Through } \\
\text { environmental- } \\
\text { forest education, }\end{array}$ & 0 & 0 & 100 & 0 & 0 \\
\hline
\end{tabular}




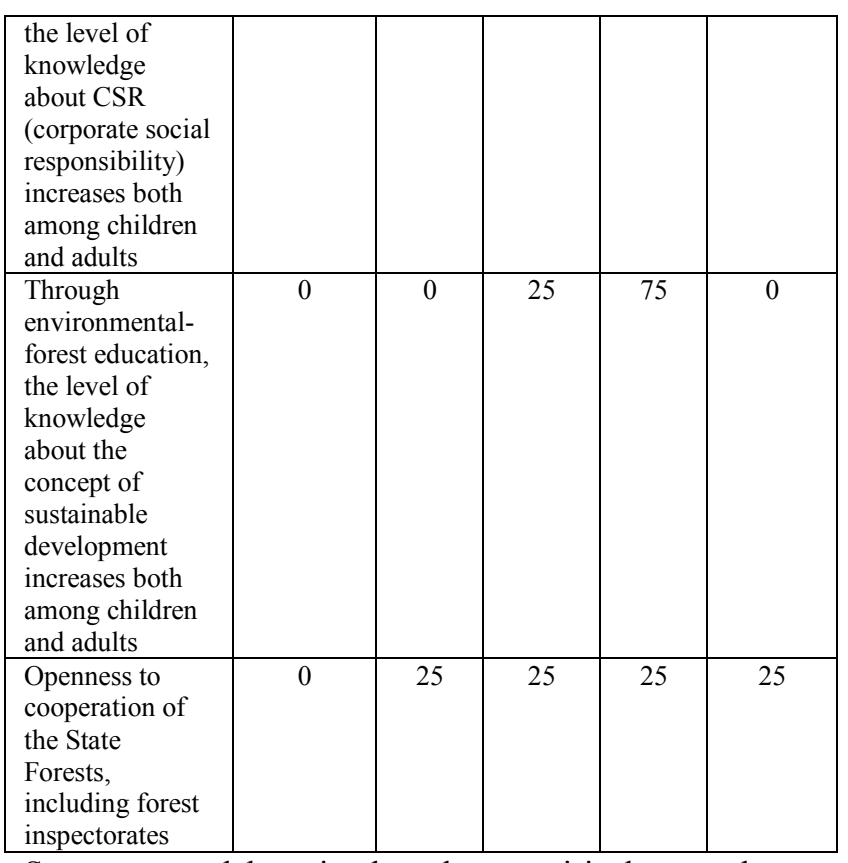

Source: own elaboration based on empirical research.

According to the respondents, environmentalists and foresters are more and more creative and have increasingly more pedagogical experience, while environmental-forestry activities are progressively more often the subject of local media's interest. National Parks and Environmental Education Centres participating in the study agree that through environmental-forest education, the level of knowledge about the concept of sustainable development increases both among children and adults. $50 \%$ of the respondents believe that the State Forests are open to cooperation with other entities within the framework of environmental-forest education.

As a result of empirical research, information was obtained that about $50 \%$ of teachers who apply environmental-forest education are not likely to be involved in this process. The respondents do not have an opinion on whether the level of society's knowledge about CSR (corporate social responsibility) increases through environmental-forest education.

This situation is caused, inter alia, by the significant workload of individual teachers and too extensive primary education programs in schools. Teachers do not have free time to work, therefore they cannot additionally engage in tasks related to nature and forest education

The next stage of empirical research was to identify weaknesses in the implementation of tasks in the field of environmental-forest education (Table
4). According to the respondents, the weakness of implementing these tasks is:

- too many participants brought to field activities (50\% of respondents),

- lack of adults interested in environmentalforest education ( $75 \%$ of respondents),

- lack of willingness to cooperate between various organizations implementing tasks in the field of environmental-forest education ( $75 \%$ of respondents).

Table 4. Weaknesses in the implementation of tasks in the field of environmental-forest education by the number of respondents' answers (\%)

\begin{tabular}{|c|c|c|c|c|c|}
\hline & $\begin{array}{c}\text { Definitel } \\
\text { y not }\end{array}$ & $\begin{array}{l}\text { Rathe } \\
\text { r not }\end{array}$ & $\begin{array}{c}\text { I have } \\
\text { no } \\
\text { opinio } \\
\mathrm{n}\end{array}$ & $\begin{array}{l}\text { Rathe } \\
\text { r yes }\end{array}$ & $\begin{array}{l}\text { Definitel } \\
\text { y yes }\end{array}$ \\
\hline $\begin{array}{l}\text { Environmentalis } \\
\text { ts and foresters } \\
\text { do not have } \\
\text { enough time to } \\
\text { get involved in } \\
\text { the issue of } \\
\text { environmental- } \\
\text { forest education }\end{array}$ & 0 & 25 & 50 & 25 & 0 \\
\hline $\begin{array}{l}\text { There is a low } \\
\text { social demand } \\
\text { for } \\
\text { environmental- } \\
\text { forest education }\end{array}$ & 0 & 75 & 25 & 0 & 0 \\
\hline $\begin{array}{l}\text { Entities } \\
\text { providing } \\
\text { environmental- } \\
\text { forest education } \\
\text { (foundations, } \\
\text { associations, } \\
\text { State Forests) } \\
\text { receive too low } \\
\text { subsidies for this } \\
\text { task }\end{array}$ & 0 & 0 & 75 & 0 & 25 \\
\hline $\begin{array}{l}\text { Too often, too } \\
\text { many } \\
\text { participants are } \\
\text { invited to field } \\
\text { classes }\end{array}$ & 0 & 25 & 25 & 0 & 50 \\
\hline $\begin{array}{l}\text { No discipline } \\
\text { during classes }\end{array}$ & 0 & 25 & 50 & 0 & 25 \\
\hline $\begin{array}{l}\text { Poorly equipped } \\
\text { educational } \\
\text { centres }\end{array}$ & 0 & 50 & 25 & 0 & 25 \\
\hline $\begin{array}{l}\text { Lack of well- } \\
\text { prepared } \\
\text { educators }\end{array}$ & 25 & 25 & 25 & 25 & 0 \\
\hline $\begin{array}{l}\text { Lack of adults } \\
\text { interested in } \\
\text { environmental- }\end{array}$ & 0 & 0 & 25 & 50 & 25 \\
\hline
\end{tabular}




\begin{tabular}{|l|l|l|l|l|l|}
\hline forest education & & & & & \\
\hline $\begin{array}{l}\text { Lack of } \\
\text { willingness to } \\
\text { cooperate } \\
\text { between various } \\
\text { organizations } \\
\text { implementing } \\
\text { tasks in the field } \\
\text { of } \\
\text { environmental- } \\
\text { forest education }\end{array}$ & & 0 & 25 & 75 & 0 \\
\hline \begin{tabular}{l} 
Source: Own \\
\hline
\end{tabular} & & & & & \\
\hline
\end{tabular}

Source: own elaboration based on empirical research.

It should be emphasized that economic practice now requires greater involvement of National Parks and schools in the scope of tasks including education in nature and forestry. The conducted empirical research indicates the marginal involvement of National Parks. The scope of services provided in this area could be extended, especially meetings with employees of the State Forests or ecologists would be valuable for the young generation. By modifying curricula, extending subject syllabuses or additional educational materials, there is a probability of more effective management of information about nature resources. Both National Parks and Environmental Education Centres participating in the study did not find weaknesses in the implementation of education tasks:

- lack of well-prepared educators $(50 \%$ of respondents),

- low social demand for environmental-forest education ( $75 \%$ of respondents),

- poorly equipped educational centres $(50 \%$ of respondents).

According to the respondents, natural resources and knowledge about them can be better managed on the basis of a prepared task plan for the protection of the National Park, the environmental and environmental-forest education programme, as well as the knowledge obtained by employees during trainings and workshops.

In the case of the snowball method, the respondents were asked about the validity of using modern tools in managing information on forestnatural resources. The results of the surveys are presented in Table 5 .

Table 5. The justification for the use of selected new technologies in environmental-forest information management by the number of respondents' answers (\%)

\begin{tabular}{|c|c|c|c|c|c|}
\hline & $\begin{array}{c}\text { Definitely } \\
\text { not }\end{array}$ & $\begin{array}{c}\text { Rather } \\
\text { not }\end{array}$ & $\begin{array}{c}\text { I have } \\
\text { no } \\
\text { opinion }\end{array}$ & $\begin{array}{c}\text { Rather } \\
\text { yes }\end{array}$ & $\begin{array}{c}\text { Definitely } \\
\text { yes }\end{array}$ \\
\hline Smartphone & 0 & 10 & 10 & 30 & 50 \\
\hline
\end{tabular}

\begin{tabular}{|c|c|c|c|c|c|}
\hline app & & 20 & 10 & 30 & 20 \\
\hline $\begin{array}{c}\text { Interactive- } \\
\text { educational } \\
\text { game on } \\
\text { smartphones }\end{array}$ & 20 & 30 & 10 & 30 & 10 \\
\hline $\begin{array}{c}\text { A game } \\
\text { using VR } \\
\text { goggles }\end{array}$ & 0 & 20 & 10 & 20 & 50 \\
\hline $\begin{array}{c}\text { Cloud usage } \\
\text { Online } \\
\text { meeting }\end{array}$ & 0 & 30 & 10 & 30 & 30 \\
\hline
\end{tabular}

Source: own elaboration based on empirical research.

According to the respondents, using new technologies in environmental information management is reasonable. The highest percentage of respondents positively referred to smartphone applications and cloud use. An educational game using VR goggles received the least recognition.

\subsection{Discussion}

Natural resources are the components of matter and energy that are used by men in the course of their activities and development. Natural, i.e. environmental, resources are of fundamental importance for the survival of the human population and further development of civilization. Environmental resources include, but are not limited to, natural riches (minerals, water, air, flora and fauna), forces of nature and environmental values that determine the quality of human life. Natural resources, their role, significance, management, aspect of sustainable development and valuation related to natural resources are widely described in the literature on the subject, among others by: Tamburlini et al.; R. Constanza .Van Der Baan; B. Poskrobko; T. Borys ; Adamowicz et al.; R. Ignatowski, M. Wójcik-Jurkiewicz; M. WójcikJurkiewicz [9-17].

Natural resources can be managed efficiently and effectively, as it is primarily done by the State Forests and other entities and institutions, such as national parks and environmental education centres. Information on activities in this field, implemented tasks and intentions aimed at protecting natural resources are, or should be, passed on to a wide range of stakeholders. These messages may be called environmental or ecological information.

Environmental information management meets the information needs of information users, provides necessary information for the management of environmental-forest education, and contributes 
to the implementation of new tasks in the field of the sustainable social and economic development of the country. As rightly pointed out by P. Szczypa [16], information on natural resources is a specific resource that:

- strongly affects economic and social conditions,

- is gaining increasing importance in decision-making processes,

- is ambiguously interpreted,

- is the key to problems related to the "prisoner's dilemma", "tragedy of the commons" and other that are based on the theory of public choice,

- is intentionally used to achieve assumed benefits (usually economic, less often ecological or social).

Environmental information is provided to the public as part of environmental-forest education. Data is transformed into information that creates knowledge. Knowledge is the basis for making various decisions and shaping information users' awareness of environmental phenomena. In this way, the information needs of various stakeholder groups are met. More details on the issues of information, environmental information, information needs and the relationship between information and knowledge and education can be found in the works of: R. Ball;; P. Dziekański ; R. Zygała ; Zając et al.; J. Oleński; Wierzbicka et al.; A. Grzywacz [19-26].

Traditional forms of spreading knowledge and information about forests and natural resources usually take place in given areas. However, the COVID-19 pandemic has shown that it is reasonable to consider the use of modern tools in managing information on natural resources, as they could significantly broaden the scope of environmental education, especially among younger people. The advantages of using individual tools are presented in Table 6.

Table 6. Modern tools for managing information on natural resources

\begin{tabular}{|c|c|c|}
\hline $\begin{array}{l}\text { Type } \\
\text { tools }\end{array}$ & Characteristics & Scope of use \\
\hline $\begin{array}{l}\text { Smartphone } \\
\text { app }\end{array}$ & $\begin{array}{l}\text { National Parks } \\
\text { Environmental or } \\
\text { Centres could create a } \\
\text { smartphone application that } \\
\text { would provide a range of } \\
\text { information about forest land. } \\
\text { The program could be a kind of } \\
\text { compendium of knowledge } \\
\text { about Poland's natural resources. } \\
\text { Examples of application }\end{array}$ & 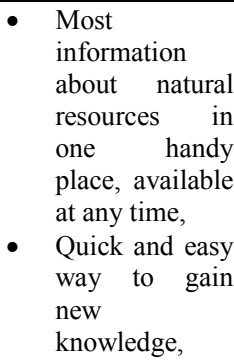 \\
\hline
\end{tabular}

\begin{tabular}{|c|c|c|}
\hline & $\begin{array}{l}\text { sections are: } \\
\text { - News } \\
\text { announcements } \\
\text { - Natural resources } \\
\text { - National parks } \\
\text { Environmental } \\
\text { Protection } \\
\text { User profile } \\
\text { The application could inform the } \\
\text { user (using smartphone location } \\
\text { permissions) about their local } \\
\text { natural resources. It could also } \\
\text { issue alerts, messages or } \\
\text { notifications about possible } \\
\text { threats (e.g. fire or drought). }\end{array}$ & $\begin{array}{l}\text { - Opportunity to } \\
\text { explore local } \\
\text { green areas, } \\
\text { - Encouragement } \\
\text { to protect the } \\
\text { environment } \\
\text { and care for } \\
\text { natural } \\
\text { resources, for } \\
\text { - Useful for } \\
\text { information } \\
\text { management. }\end{array}$ \\
\hline $\begin{array}{l}\text { Interactive- } \\
\text { educational } \\
\text { game on } \\
\text { smartphones }\end{array}$ & $\begin{array}{l}\text { The use of smartphones in the } \\
\text { dissemination of environmental } \\
\text { education could be associated } \\
\text { with the creation of educational } \\
\text { games. It could be a simple } \\
\text { platform or a role-playing game } \\
\text { in which the user would take the } \\
\text { role of a wanderer. Their task } \\
\text { would be to collect specific } \\
\text { resources in National Parks. } \\
\text { This, in turn, would be possible } \\
\text { by giving correct answers asked } \\
\text { by the encountered foresters in } \\
\text { quizzes. The game could also } \\
\text { use AR technology, i.e. } \\
\text { augmented reality. In this } \\
\text { technology, virtual elements are } \\
\text { imposed on the surrounding } \\
\text { reality. }\end{array}$ & 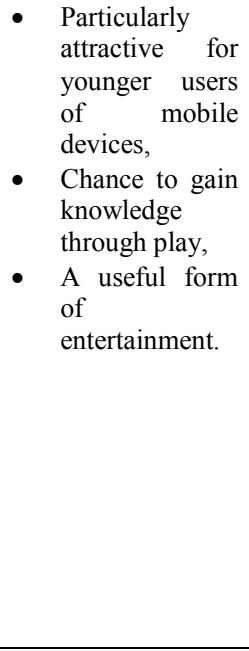 \\
\hline $\begin{array}{lr}\text { A } & \text { game } \\
\text { using } & \text { VR } \\
\text { goggles } & \end{array}$ & $\begin{array}{l}\text { Not everyone has the } \\
\text { opportunity to experience the } \\
\text { charms of forest land in person. } \\
\text { In this case, it would be possible } \\
\text { to create a game using VR } \\
\text { goggles. After putting on the } \\
\text { appropriate glasses, the user will } \\
\text { find themselves in a virtual } \\
\text { forest, where they will see } \\
\text { animals or other natural } \\
\text { resources. This type of } \\
\text { programme could also include } \\
\text { tasks and missions for the user } \\
\text { to increase their knowledge of } \\
\text { natural resources. }\end{array}$ & $\begin{array}{l}\text { - An attractive } \\
\text { form of } \\
\text { entertainment } \\
\text { and education } \\
\text { for young } \\
\text { people, } \\
\text { - Possibility of } \\
\text { feeling an } \\
\text { ersatz of the } \\
\text { forest for } \\
\text { people with } \\
\text { limited } \\
\text { mobility, such } \\
\text { as the disabled. }\end{array}$ \\
\hline Cloud usage & $\begin{array}{l}\text { Cloud technology allows a wide } \\
\text { range of data transfer and } \\
\text { storage. It would be particularly } \\
\text { useful for foresters or people } \\
\text { who spread environmental- } \\
\text { forest education. All current } \\
\text { data on, for example, the general } \\
\text { condition of National Parks, soil } \\
\text { irrigation, the number of people } \\
\text { visiting forest land, and fire } \\
\text { hazards could be sent to the } \\
\text { cloud on an ongoing basis and } \\
\text { from there to smartphones or } \\
\text { multimedia screens at the park } \\
\text { entrances. The cloud is also a } \\
\text { very good way of } \\
\text { communication between } \\
\text { foresters. Appropriate tools are } \\
\text { provided by technology } \\
\text { companies such as Microsoft, }\end{array}$ & $\begin{array}{l}\text { - Ideal for } \\
\text { storing and } \\
\text { transmitting } \\
\text { data on natural } \\
\text { resources, } \\
\text { - Supports } \\
\text { environmental- } \\
\text { forest } \\
\text { education, } \\
\text { - Useful for } \\
\text { foresters and } \\
\text { educators, } \\
\text { - Indispensable } \\
\text { in information } \\
\text { management. }\end{array}$ \\
\hline
\end{tabular}




\begin{tabular}{|c|c|c|}
\hline & Google or Polish Comarch. & \\
\hline $\begin{array}{l}\text { Online } \\
\text { meetings }\end{array}$ & $\begin{array}{l}\text { The COVID- } 19 \text { pandemic has } \\
\text { shown that direct meetings in } \\
\text { larger groups are not always } \\
\text { needed. In such cases, it is } \\
\text { possible to use online meeting } \\
\text { tools for environmental-forest } \\
\text { education. The tools are } \\
\text { provided by the following } \\
\text { companies: Microsoft (Teams, } \\
\text { Skype) Google (Hangouts), } \\
\text { Zoom (Zoom application) and } \\
\text { Slack. }\end{array}$ & $\begin{array}{l}\text { A good way } \\
\text { for education } \\
\text { without } \\
\text { leaving } \\
\text { home, } \\
\text { A safe and } \\
\text { quick way to } \\
\text { exchange } \\
\text { views and } \\
\text { discussions. }\end{array}$ \\
\hline
\end{tabular}

Source: own elaboration

As shown in the table, each of the new opportunities to spread environmental-forest knowledge would work in a different area. The multitude of tools and options of new technologies allows reaching a larger group of potential recipients. The use of such tools would be associated with the costs of their implementation [27]. However, many advantages would add value to each project.

More on the issue of environmental-forest education in works [28-34].

The process of environmental-forest education is part of the current forest management. Education is a process of teaching and upbringing, i.e. consciously affecting a person to shape their consciousness. One should agree [35] that the natural resources science is dominated by the causeand-effect thinking of learners. The measure of effective assimilation and understanding of mechanisms and processes occurring in the natural environment is the ability to observe, experience and experiment. Currently, the management of natural resources using environmental-forest education as a generator of information on phenomena related to the natural environment is becoming the key factor. Therefore, forms of environmental-forest education and the number of participants taking part in these events are important nowadays. Thus, it is postulated to look for new forms of environmental-forest education and to gradually increase the number of participants in these classes.

\section{Conclusion}

Both the results of literature research and empirical studies carried out confirmed that:

1. Environmental-forest education is conducted on a large scale by the State Forests with the support of national parks and environmental education centres.

2. Various forms of environmental-forest education are used. Its most commonly used forms include meetings with foresters and thematic workshops.
3. There is a diverse number of participants in environmental-forest education classes. Participants of educational classes are mainly students of kindergartens, elementary schools and high schools. A positive trend is the participation of people with disabilities in activities involving education about natural resources.

4. There is difficult access to data on the level of costs and expenses related to environmentalforest education. Expenses and costs are not identified on analytical accounts.

5. The strengths of environmental-forest education include the growing pedagogical experience of environmentalists and foresters, as well as their creativity. The strength of education is also the growing interest in this activity of local media and the fact that through environmental-forest education, the level of knowledge about the concept of sustainable development increases both among children and adults.

6. The weak point of the activities in the field of environmental-forest education is that often too many participants are brought to field activities, as well as the lack of willingness to cooperate between various organizations implementing tasks in the field of environmental-forest education.

7. Environmental-forest education contributes to the management of information on natural resources.

8. It is proposed to take effective measures to manage information on natural resources by:

- developing plans for the success of environmental-forest education,

- $\quad$ creating new educational trails,

- engaging elementary school teachers to

work together as part of environmental-forest education,

- $\quad$ introducing one multimedia environmental lesson on natural resources (obligatory),

- introducing one obligatory lesson with foresters (per month or on a quarterly basis) in elementary schools, high school and college.

9. The use of new technologies in managing information on natural resources would allow:

- gaining knowledge about forests and the environment for more people,

- $\quad$ protecting the natural environment even better (an educated person is a less harmful person),

- managing information and communication among foresters and educators better,

- $\quad$ saving time of the educated and educators,

- $\quad$ expanding traditional education with new, attractive methods,

- introducing green areas to people who previously did not know them, 
- $\quad$ warning those using forest and natural areas against current threats.

9. The results of scientific research in this study allowed for the isolation of the scientific contribution on the theoretical level, i.e. the confrontation (analysis) of the functioning economic theories, including the theory of stakeholders and the theory of information usefulness. The review of the above theories allowed for their adaptation to the theoretical approach to the process of managing information about natural resources. Additionally, the literature on the subject was reviewed (domestic and foreign) in the context of the implementation of the information function by the entities. On the methodological level, the authors' own contribution equals the formulated conclusions and recommendations that should be adapted by business practice in order to improve the process of nature and forest education.

\section{References:}

[1] National Strategy for Environmental Education through education to sustainable development, 2001. Ministry of the Environment. Warszawa, p. 8.

[2] Wójcik-Jurkiewicz M., The idea of socially responsible business and shaping the company's financial result. Economic Studies, Zeszyty Naukowe Uniwersytetu w Katowicach No. 253, 2016.

[3] Milewska B., Milewski D., Logistics problems at the Centre for Forest Transportation in Szczecin, Zeszyty Naukowe - Uniwersytet Szczeciński no. 130. Works of the Faculty of Transport, 1994, pp. 181-185.

[4] The Forest Act of 28 September 1991. Journal of Laws no. 101, item 444, as amended.

[5] The Strategy of State Forests National Forest Holding for the years of 2014-2030. 2013.

[6] Olcomendy, L., Santos-Cessac, F., Dondon Ph., Design of a low cost LIDAR scan system for didactical applications, International Journal of Circuits, Systems and Signal Processing, s. 366372, tom 13, 2019.

[7] Ding D., Zhu S., A Method of Forest-Fire Image Recognition Based on AdaBoost-BP Algorithm, International Journal of Circuits, Systems and Signal Processing, s. 312-319, tom 13, 2019.

[8] Ankudo-Jankowska A., Starosta-Grala M., Sadowska B., Kożuch A., The use of external sources in financing environmental-forest education in regional directorates of the State Forests, 2019, Sylwan 163 (2):158-167.
[9] Constanza R. (red.), The value of the world's ecosystem services and natural capital, "Nature", no. 387, 1997, pp. 253-260.

[10] Borys, T., New directions in the economics of the environmental and natural resources in the aspect of the new financial perspective of the European Union, Ekonomia i środowisko, 2013, (1 [44]).

[11] Tamburlini G., von Ehrenstein O.S., Bertollini R., Children's health and environment: A review of evidence. Environmental issue report, 29, European Environmental Agency, 2002, Copenhagen.

[12]Van Der Baan P., Working and learning in the word of Cradle - to - Cradle (C2C) - an European Network on Education for Responsible Living. Zesz. Nauk. South-East. Offices of PTIE and PTG in Rzeszów, 2012, 15: 15-24 [electronic document: http://www2.univ.rzeszow.pl/wbr/zeszyty/].

[13] Adamowicz, K., Kożuch, A., \& Jaszczak, R., The concept of using ex-post analysis to prepare an economic annex to the forest management plan. 2016, Sylwan, 160(11), 883-892.

[14] Wójcik-Jurkiewicz M., Berniak-Woźny J., Sroka R., Non-financial reporting of the financial sector in Europe In light of new EU regulations and selected international trends. Knowledge for Market Use 2018: Public Finances in the Background of Sustainable Development. Pavla Slavíčková - Tomáš Talášek (Eds.), s. 496-503.

[15] Poskrobko B., A new approach to natural wealth as the basis for retardation of the use of resources. KPZK PAN Bulletin, 2010, 242: 90 108.

[16] Wójcik-Jurkiewicz M., Role of CSR reporting. Evidence from Poland. Economy, Business Ethics. Stowarzyszenie Księgowych w Polsce, 2017, s. 173-188.

[17] Ignatowski, R., \& Wójcik-Jurkiewicz, M., Raportowanie spótek $w$ zakresie społecznie odpowiedzialnego biznesu [w:] Z. Dobrowolski, G. Ignatowski, Ł. Sułkowski (red.), Instrumenty polityki społecznej, Difin, Warszawa 2016, 124142.

[18] Szczypa, P., Environmental information contemporary dilemmas. Social inequalities and economic growth, 2015, 2(44), 275-285.

[19] Ball R., The scientific information environment in the next millennium, 2000, "Library": 10-12. Management", vol. 21, no. 1.

[20] Czaja S. Information as the basis for shaping sustainable development and knowledge-based 
economy [in:] Sustainable development of the knowledge-based economy, 2009, eds. B. Poskrobko, Wydawnictwo Wyższej Szkoły Ekonomicznej w Białymstoku, Białystok: 192.

[21] Dziekański, P., Information as an economic asset that is a source of competitive advantage. Social inequalities and economic growth, The University of Business and Entrepreneurship in Ostrowiec Świętokrzyski, 2012, 24, 387-403.

[22] Grzywacz A., Core curriculum in primary schools in the field of knowledge about the forest and the forest education content implemented by the State Forests. CEPL Studies and Materials. Trends and news in the forest educational infrastructure. Rogów, 2011.

[23] Oleński J., Information economics. Methods, PWE, Warszawa, 2003.

[24] Wierzbicka A., Glura J., Chmura A., Does knowledge matter? Social attitude to hunters in RDSF Szczecin. CEPL Studies and Materials in Rogów. Modern Technologies for Forest Education, 2015, Rogów: 99-107.

[25]Zygała R., Basics of enterprise information management, Wydawnictwo Akademii Ekonomicznej we Wrocławiu, Wrocław 2007.

[26]Zając, A., \& Kuraś, M., Research on information needs. Zeszyty Naukowe, Uniwersytet Ekonomiczny w Krakowie, 2009, (770), 37-55.

[27]Zimon, G., Financial liquidity management strategies in Polish energy companies, International Journal of Energy Economics and Policy, 2020, Vol.10, No 3, pp.365-368.

[28] Chrzanowski P., A forest education model of the society? Las polski 3/2016, 1-15 February.

[29] Starosta-Grala M., Ankudo-Jankowska A., Legal conditions of environmental-forest education in Poland. 2016, Acta Sci. Pol. Silv. Colendar. Ratio Ind. Lignar. 15(3).

[30] Varela-Candamio L., Novo-Corti I., García-Alvarez M. T., The importance of environmental education in the determinants of green behavior: A meta-analysis approach. Journal of Cleaner Production 170: 1565-1578, 2018.

[31] Ordinance No. 57 of the Director-General of State Forests of May 9, 2003 on guidelines for conducting forest education for the public in the State Forests.

[32] Farmer J., Knapp D., Benton G. M., An elementary school environmental education field trip: long-term effects on ecological and environmental knowledge and attitude development. The Journal of Environmental Education, 2007, 38 (3): 33-42.

[33] Walker K. E., Challenging critical theory in environmental education. Environmental Education Research 3 (2): 155-162, 1997.

[34] Woźnicka M., Janeczko E., Kargul-Plewa D., The value of the forest in environmental-forest education. CEPL Studies and Materials in Rogów. Milestones of 20 years of forest education in Poland, 2016, R.15. Zeszyt 47/2. Rogów.

[35] Falencka-Jabłońska M., Effective and attractive methods of learning the laws of nature. CEPL Studies and Materials in Rogów. Milestones of 20 years of forest education in Poland. Rogów, 2016.

\section{Contribution of individual authors to the creation of a scientific article (ghostwriting policy)}

Beata Sadowska, Adam Lulek -Conceptualization Beata Sadowska, Adam Lulek - writing-review and editing

Beata Sadowska, Adam Lulek was responsible for the Statistics and writing - original draft preparation

\section{Sources of funding for research presented in a scientific article or scientific article itself}

There is not any sources

\section{Creative Commons Attribution License 4.0 (Attribution 4.0 International, CC BY 4.0)}

This article is published under the terms of the Creative Commons Attribution License 4.0 